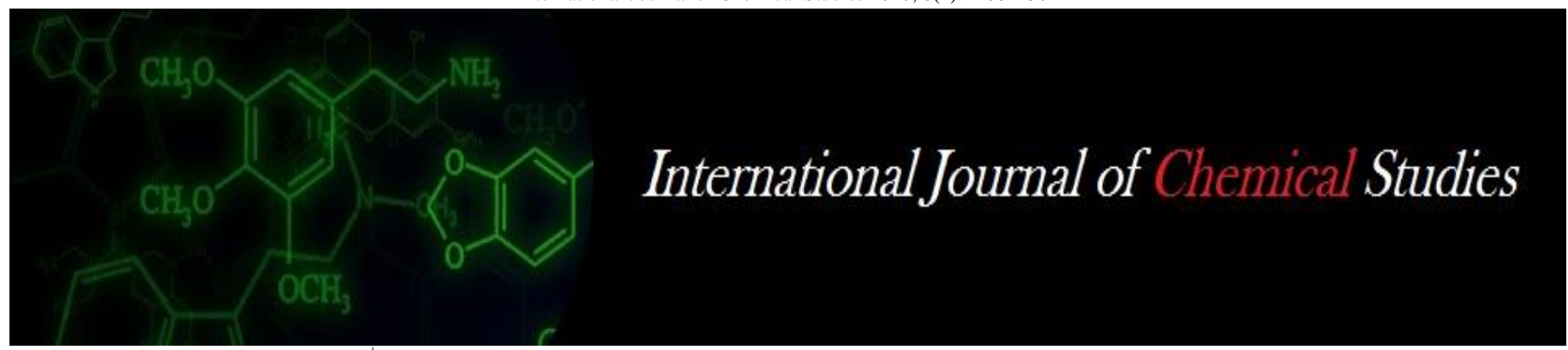

P-ISSN: 2349-8528

E-ISSN: 2321-4902

www.chemijournal.com

IJCS 2020; 8(2): 1499-1502

(C) 2020 IJCS

Received: 10-01-2020

Accepted: 12-02-2020

\section{Mohammad Nasim}

Plant Protection Department, Agriculture Faculty, Laghman University, Laghman Province, Afghanistan

Mohammad Ikram Azizi Plant Protection Department, Agriculture Faculty, Laghman University, Laghman Province, Afghanistan

Shukrullah Shwoban Agricultural Economics and Extension Department, Agriculture Faculty, Laghman University, Laghman Province, Afghanistan
Corresponding Author: Mohammad Ikram Azizi Plant Protection Department, Agriculture Faculty, Laghman University, Laghman Province, Afghanistan

\title{
Management of Alternaria blight of sunflower through fungicides
}

\section{Mohammad Nasim, Mohammad Ikram Azizi and Shukrullah Shwoban}

DOI: https://doi.org/10.22271/chemi.2020.v8.i2w.8973

\section{Abstract}

The present study was conducted to evaluate the efficacy of fungicides. Crop was sown in Randomized Complete Block Design and fourteen treatments were applied with three replications. Plot size of $4.2 \mathrm{~m} \mathrm{x}$ $3.0 \mathrm{~m}$ with spacing of $60 \mathrm{~cm} \times 30 \mathrm{~cm}$ was maintained. All the recommended package of practices was applied to raise the crop except the disease management practices.

Treatments were of non-systemic, systemic and combination fungicides. Minimum disease severity $16.3 \%$ was observed in $\mathrm{T}_{11}$ (foliar application of Difenconazole @ $0.1 \%$ ) and it was significantly lower than all other treatments. $\mathrm{T}_{10}$ (foliar application of Difenconazole @ $0.05 \%$ ) gave disease severity of 20.4 percent (PDI) which was followed by $\mathrm{T}_{7}$ (Hexaconazole 5EC @ 0.2\%), T9 (Tebuconazole 25EC @ $0.1 \%), \mathrm{T}_{4}$ (Tebuconazole + Trifloxystrobin@ 0.05\%), $\mathrm{T}_{8}$ (Tebuconazole $\left.25 \mathrm{EC} @ 0.05 \%\right)$ and $\mathrm{T}_{5}$ (Tebuconazole + Trifloxystrobin @ 0.1\%). The highest seed yield was observed in $\mathrm{T}_{11}$ (foliar application of Difenconazole @ 0.1\%) and $\mathrm{T}_{10}$ (foliar application of Difenconazole @ 0.05\%) treatments.

Keywords: Oilseeds, alternaria blight, disease management, seed yield, fungicides

\section{Introduction}

Oilseeds form the second largest agricultural commodity after cereals, sharing $14 \%$ of country's gross cropped area accounting nearly 5\% of Gross National Product (GNP) and 10\% of the value of all agricultural products Shankergoud et al. (2006) ${ }^{[21]}$. Sunflower (Helianthus annus L.) is native of Southern USA and Mexico; an important oilseed crop of family Asteraceae ranks third next to groundnut and soybean. It is a rich source of edible oil (40-52\%) having anti-cholesterol properties due to the presence of polyunsaturated fatty acids (PUFA, $55-65 \%$ linoleic acid \& 20-30\% oleic acid) which are known to reduce the risk of coronary diseases Joksimovic et al. (2006) ${ }^{[9]}$. The large scale cultivation of sunflower in India was started in 1972 with the introduction of high yielding Russian varieties.

Sunflower is the $4^{\text {th }}$ most important oilseed crop, cultivated throughout India which accounts about 0.43 MT of annual production with a productivity of $736 \mathrm{~kg} / \mathrm{ha}$ from 0.59 Mha area Anonymous (2015) ${ }^{[3]}$. It is mostly valued for its high quality edible oil, i.e. extracted from the seed (22-36\%) and kernel (45-55\%). The expressed oil is of light amber coloured with a mild, pleasant flavour which is high in vitamin E, unsaturated fatty acids; mono-unsaturated fatty acids $(30 \%)$, polyunsaturated fatty acids (59\%) and low in saturated fats; palmitic acid (5\%) and stearic acid (6\%). It is also a good source of $\mathrm{Zn}$ and folate that provide several health benefits. Besides consumption, the oil is also used in cosmetic and paint industries, the seeds are used as seed meal for live stocks and dried plants as fuel. Being a short duration (100-110 days) and photo-thermo insensitive crop, sunflower can fit easily in any cropping pattern and can be cultivated throughout the year.

Sunflower cultivation is largely confined to southern parts of the country comprising the states of Andhra Pradesh, Karnataka, Maharashtra and Tamil Nadu. The four states contribute about $90 \%$ of the total acreage and $78 \%$ of total production. Among these states, Karnataka stands first. Under optimum conditions, sunflower has the yield potential of 2.0 to 2.5 ton/ ha as against its national low productivity level of $736 \mathrm{~kg} / \mathrm{ha}$ in India. Despite the rapid spread of the crop, the disheartening trend is that, the productivity is going down, in recent years. The potential of the crop is, far from being exploited and the yield levels of the country are the lowest in the world due to several biotic and abiotic stresses. At present, the sunflower productivity in India is $608 \mathrm{~kg} / \mathrm{ha}$ as mentioned above and in Karnataka it is $372 \mathrm{~kg} / \mathrm{ha}$ less 
than the national average. Among several biotic stresses for successful sunflower production, the susceptibility to the diseases is one of the major constraints. Gulya and Masirevic (1991) ${ }^{[7]}$ have listed 80 pathogens infecting sunflower. In Karnataka, the major diseases on sunflower viz., necrosis virus disease, Alternaria blight, rust, collar rot and downy mildew are among these, Alternaria blight caused by Alternaria helianthi (Hansf) Tubaki and Nishihara has been considered as a potentially destructive disease in many parts of the sunflower growing countries Allen et al. (1983) [1]; Morris et al. (1983) ${ }^{[16]}$ and Lipps and Herr, (1986) ${ }^{[12]}$, and in India, the disease has been reported in all sunflower growing states (Shankergoud et al. (2006) ${ }^{[21]}$.Further this disease is known to cause reduction in flower size, number of seeds per head, seed yield per plant, test weight and also oil content Balasubramanyam and Kolte (I980) ${ }^{[4]}$. The loss in yield varies from 11.30 to 73.33 per cent depending on the extent of infection Reddy and Gupta, (1977) ${ }^{[20]}$. Alternaria leaf blight is known to cause more than 80 per cent of yield loss under severe epiphytotic conditions Hiremath et al. (1990) ${ }^{[8]}$.The disease is particularly destructive in tropical and sub-tropical regions wherein a combination of high temperature and extended periods of humid weather cause rapid epidemics Sujatha et al. (1997) [22]; Dudienas et al. (1998) ${ }^{[6]}$. Under these conditions, the pathogen causes premature senescence and rapid defoliation Kong et al. (1995) [11]. Seed yield is reduced up to $70 \%$ together with significant reduction in quantity and quality of oil Kolte (1984) ${ }^{[10]}$. Disease symptoms appear more predominantly on older leaves than on young and expanding ones. Plants are highly susceptible during anthesis and foliage reduction at this stage results in $80 \%$ loss in yield Carson, (1985) ${ }^{[5]}$.

\section{Materials and Methods}

During the present investigations on management of Alternaria blight (Alternaria helianthi (Hansf.) Tubaki and Nishihara) of sunflower (Helianthus annus.), all the experiments were conducted (in vivo) at Oilseeds section in the Department of Plant Breeding and Genetic PAU Ludhiana during spring 2018, to fulfill the objectives defined, the details of the materials used and methods adopted for various experiments are described here in the following paragraphs.

Standard chemicals, reagents, fungicides, fertilizers etc. required for the experimentation were obtained from the Oilseed Research Station, Punjab Agriculture University and Department of Plant Pathology College of Agriculture, PAU Ludhiana.

The common glass-wares (Borosil and Coming Make) viz., Petridishes, test tubes, conical flasks, volumetric flasks, measuring cylinder, glass rods, beakers, funnel, pipettes etc. were obtained from the Department of Plant Breeding and Genetics.

Sunflower seeds of hybrid PSH (1962). Were surface sterilized with 0.1 per cent mercuric chloride and sown in earthen pots containing sterilized soil. They were allowed to grow for 30 days. The plants were predisposed to 95 per cent humidity for 24 hours. Thereafter, they were inoculated with spore suspension of $\left(5.4 \times 10^{6}\right.$ spores/ $\left.\mathrm{ml}\right)$ the fungus, by using atomizer. After inoculation the plants were exposed in the same conditions for 24 hours. Suitable control plants were maintained by spraying of sterile distilled water. Symptoms appeared after five days. The organism was re-isolated from these artificially infected leaves and the culture obtained was compared with the original culture for confirmation.
The field experiment was conducted on the research farm of the Oilseed Section, plant Breeding and Genetic during spring, 2018, to evaluate the efficacy of fungicides. The seed PSH 1962 ware provided by oil seed section plant breeding and genetic Section Oilseed Research Station, Plant Breeding and Genetic Section PAU, Ludhiana. Fungicides were obtained from the Department of Plant Breeding and Genetic College of Agriculture PAU, Ludhiana.

Research design: Crop was sown in Randomized Complete Block Design and fourteen treatments (such as T1: Mancozeb @ 0.2\%, T2: Azoxystrobin 23 SC +Difenoconazole @ 0.05\%, T3: Azoxystrobin 23 SC +Difenoconazole @ $0.1 \%$, T4:Tebuconazole +Trifloxystrobin @ $0.05 \%$, T5: Tebuconazole +Trifloxystrobin @ 0.1\%, T6: Hexaconazole 5 EC @ 0.1\%, T7: Hexaconazole 5 EC @ 0.2\%, T8: Tebuconazole 25 EC @ 0.05\%, T9: Tebuconazole 25 EC @ 0.1\%, T10: Difenconazole @ 0.05\%, T11: Difenconazole @ $0.1 \%$, T12: Chlorothalonil @0.15\%, T13: Chlorothalonil @ $0.3 \%$ and T14: Control - untreated) were applied with three replications. Plot size of $4.2 \mathrm{~m} \times 3.0 \mathrm{~m}$ with spacing of $60 \mathrm{~cm} \mathrm{x}$ $30 \mathrm{~cm}$ was maintained. All the recommended package of practices was applied to raise the crop except the disease management practices. Following treatments were applied at PAU, Ludhiana.

\section{Disease incidence}

Observations of disease incidence and disease intensity were recorded at appearance of visible spots of $A$. helianthi to quantify amount of Altenaria infection. Disease incidence was calculated from the number of infected plant against the total number of plants existed at the time of observation. Thus formula of per cent incidence was

$$
\text { Percent incidence }(P I)=\frac{\text { No. of plants infected }}{\text { Total no. of plants observed }}
$$

\section{Percent disease intensity / severity}

Percent intensity (severity) was calculated as per the standard area diagram developed by Mayee and Datar (1986) ${ }^{[14]}$. For recording the disease intensity at field conditions 0 to 9 disease rating scale developed by Mayee and Datar was used. For this purpose two leaves located at the bottom, two at middle and two top of the plant were chosen and scored as per scale given below.

The average intensity of each plot was worked out by using following formula

$$
\text { P.D.I. }=\frac{\text { Summation of all numerical ratings }}{\text { Total no. of plant } \mathrm{x} \text { Maximum rating scale observed }}
$$

Where,

PDI $=$ Percent disease intensity .

\section{Percent disease control}

Per cent disease control (PDC) was worked out by applying the Formula

$$
\mathrm{PDC}=\frac{\text { PDI in control plot }- \text { PDI in treatment plot }}{\text { PDI in control plot }} \times 100
$$




\section{Results and Discussion}

Among the different foliar diseases of sunflower, Alternaria blight caused by Alternaria helianthi (Hansf.) Tubaki and Nishihara is one of the major diseases, causing a yield loss up to 80 per cent. Hence, the present investigations on epidemiology and management of Alternaria blight of sunflower were carried out in the field during spring, 2018, at Oilseeds Section, Department of Plant Breeding \& Genetics, College of Agriculture, and Ludhiana. The results thus obtained are presented hereunder.

The disease appeared in the form of small, scattered brown spots on the leaf lamina. Later these spots increased in size and coalesced covering larger leaf area, with dark brown margin and yellow halo. Necrotic lesions appeared even on stem, petioles and sepals. The symptoms observed on different plant parts are depicted in plate 1 .

Disease management experiment through fungicides was conducted during spring 2018 at PAU, Ludhiana. The experiment was laid out in RCBD with fourteen treatments and replicated thrice.The seeds of sunflower hybrid PSH 1962 were sown at spacing of $60 \times 30 \mathrm{~cm}$. All the recommended agronomic practices were followed throughout the experiment. The data on per cent disease incidence and seed yield were collected from all the locations and data was pooled.

Results at Ludhiana (Table 1) revealed that the minimum disease severity (16.3\%) was observed in $\mathrm{T}_{11}$ (foliar application of Difenconazole @ $0.1 \%$ ) and it was significantly lower than all other treatments. $\mathrm{T}_{10}$ (foliar application of Difenconazole @ $0.05 \%$ ) gave disease severity of 20.4 percent (PDI) which was followed by $\mathrm{T}_{7}$ (Hexaconazole 5EC @ $0.2 \%), \mathrm{T}_{9}$ (Tebuconazole 25EC @0.1\%), $\mathrm{T}_{4}$ (Tebuconazole + Trifloxystrobin @ 0.05\%), $\mathrm{T}_{8}$ (Tebuconazole 25 EC @ $0.05 \%$ ) and $\mathrm{T}_{5}$ (Tebuconazole + Trifloxystrobin@ @ $0.1 \%$ ). The maximum disease severity $(46.5 \%)$ was observed in $\mathrm{T}_{1}$ (seed treatment with mancozeb).

At Ludhiana maximum disease control of 69.9 percent was recorded in treatment $\mathrm{T}_{11}$ (foliar application of Difenconazole @ $0.1 \%$ ) and next to it was at foliar application of Difenconazole@0.05 percent $(62.4 \%)$. The conclusion from the results is that $\mathrm{T}_{11}$ (foliar application of Difenconazole $@ 0.1 \%$ ) and $\mathrm{T}_{10}$ (foliar application of Difenconazole @ $0.05 \%$ ) proved best in controlling the Alternaria blight disease at PAU, Ludhiana.

Many fungicides were tested against the pathogen Alternaria spp. and in sunflower similar fungicide groups were found effective. Chemical management with protective (nonsystemic) fungicides such as iprodione, chlorothalonil, and mancozeb as well as with therapeutic (systemic) fungicides such as hexaconazole, carbendazim, and propiconazole has been found effective against the disease. But systemic fungicides were more effective than the nonsystemic ones Amaresh et al. (2004) ${ }^{\text {[2] }}$. Seed treatment with a mixture of carbendazim + iprodione in a $1: 1$ ratio at $0.3 \%$ followed by foliar spray of systemic fungicide hexaconazole $(0.1 \%)$ gave best management of the disease with high yield Rao et al. (2009) [19]. Combination of carbendazim + mancozeb in the ratio of $1: 1$ at $0.2 \%$ spray used effectively in the management of the disease avoiding the possibility of fungicide-resistant strains of the pathogen (Mathivanan and Prabavathy 2007) ${ }^{[13]}$.

Wadibhasme et al. (1991) ${ }^{[24]}$ conducted field trial for three years and found mancozeb most superior amongst all the fungicides followed by triademefon, chlorothalonil and ziram, which were at par with each other. Rao and Nageshwar Rao (1997) [18] reported that three sprays of mancozeb on sunflower at 30, 45 and 60 days after sowing were found to be effective in controlling Alternaria and increased the yield significantly in Morden variety. Rao et al. (2009) ${ }^{[19]}$ treated seeds with carbendazim+iprodione at $0.3 \%$ in poly ethylene glycol along with foliar spray of hexaconazole, this treatment recorded least percent disease indexes of 19.24, 28.86 and $37.74 \%$ at 45,60 and 75 DAS, respectively, seed treatment with carbendazim+iprodione at $0.3 \%$ in water along with foliar spray of hexaconazole was found most effective in managing Alternaria blight with maximum benefit-cost ratio. Mesta et al. (2003) ${ }^{[15]}$ found significant differences between treatments with respect to PDI, seed yield, oil content and oil yield. At 75 DAS, hexaconazole $(0.1 \%)$ recorded lowest PDI (35.63), which was on par with propiconazole (37.80) and was significantly lesser than all other treatments. Iprodione +carbendazim (44.16) was next in order followed by penconazole (48.16), difenconazole (53.44) and mancozeb (54.41). Prasad et al. (2015) ${ }^{[17]}$ observed that seed treatment with iprodione + carbendazim $2 \mathrm{~g} / \mathrm{kg}$ along with foliar application of propiconazole $(0.1 \%)$ twice at 15 days interval showed more reduction in leaf blight during $2008(21.7 \%)$, 2009 (31.8\%) and 2010 (30.4\%). Vijayalakshmi et al. (2018) [23] evaluated three fungicides for management of Alternaria blight disease spraying and found Propiconozole $(0.1 \%)$ with highest yield of $2181.71 \mathrm{~kg} / \mathrm{ha}$ and a least disease severity of 9.85 per cent followed by 13.91 percent with seed treatment and spraying with Mancozeb and 18.11 percent disease severity in seed treatment and spraying with Iprodione+Carbendazim. The highest disease severity (46.03 per cent) was recorded in control.

Table 1: Effect of different fungicide treatments on disease index and seed yield of sunflower (Ludhiana)

\begin{tabular}{|c|c|c|c|c|}
\hline Treatments & Percent Disease IndexII & Percent Disease control & Seed yield (q/ ha) & Percent yield increase \\
\hline T1: Mancozeb @ 0.2\% & \begin{tabular}{|l|l|}
$46.5(43.0)$ \\
\end{tabular} & \begin{tabular}{|c|}
14.2 \\
\end{tabular} & 20.23 & 4.1 \\
\hline T2: Azoxystrobin 23 SC + Difenoconazole @ 0.05\% & $36.7(37.2)$ & 32.3 & 22.46 & 15.5 \\
\hline T3: Azoxystrobin 23 SC + Difenoconazole @ 0.1\% & $33.0(34.9)$ & 39.1 & 23.01 & 18.4 \\
\hline T4: Tebuconazole + Trifloxystrobin @ 0.05\% & $26.3(28.3)$ & 51.5 & 24.60 & 26.5 \\
\hline T5: Tebuconazole + Trifloxystrobin @ 0.1\% & $22.6(28.4)$ & 58.3 & 25.13 & 29.3 \\
\hline T6: Hexaconazole 5 EC @ 0.1\% & $25.9(30.5)$ & 52.2 & 25.60 & 31.7 \\
\hline T7: Hexaconazole 5 EC @ 0.2\% & $22.0(27.6)$ & 59.4 & 26.17 & 34.6 \\
\hline T8: Tebuconazole 25 EC @ 0.05\% & $24.3(28.3)$ & 55.2 & 24.89 & 28.0 \\
\hline T9: Tebuconazole 25 EC @ 0.1\% & $21.3(27.8)$ & 60.7 & 25.99 & 33.7 \\
\hline T10: Difenconazole @ 0.05\% & $20.4(26.3)$ & 62.4 & 26.40 & 35.8 \\
\hline T11: Difenconazole @ 0.1\% & $16.3(23.4)$ & 69.9 & 27.14 & 39.6 \\
\hline T12: Chlorothalonil @0.15\% & $38.0(38.3)$ & 29.9 & 20.12 & 3.5 \\
\hline T13: Chlorothalonil @ $0.3 \%$ & $34.8(36.2)$ & 35.8 & 21.32 & 9.8 \\
\hline T14: Control - untreated & $54.2(48.3)$ & & 19.44 & \\
\hline $\mathrm{CD}$ & 4.1 & & 3.26 & \\
\hline
\end{tabular}




\begin{tabular}{|c|c|c|c|}
\hline CV & 9.3 & & 11.5 \\
\hline SEM & 1.3 & & 1.5 \\
\hline
\end{tabular}

\section{Seed yield (q/ha)}

The highest seed yield at Ludhiana was recorded in $\mathrm{T}_{11}$ (Difenconazole @0.1\%) (27.14 q/ ha) and it was followed by $\mathrm{T}_{10}$ (Difenconazole @0.05\%) (26.4 q/ h), $\mathrm{T}_{7}$ (Hexaconazole 5EC@0.2\%) (26.17 q/ ha), T9 (Tebuconazole 25 EC @0.1\%) (25.99 q/ ha), T 8 (Tebuconazole25 EC @0.05\%) (24.89 q/ ha), $\mathrm{T}_{6}$ (Hexaconazole 5EC@ 0.1\%) (25.60 q/ ha), $\mathrm{T}_{5}$ (Tebuconazole + Trifloxystrobin @ 0.1\%) (25.13 q/ ha), $\mathrm{T}_{4}$ (Tebuconazole + Trifloxystrobin@ 0.05\%) (24.60 q/ ha). The lowest seed yield was observed in $\mathrm{T}_{12}$ (Chlorothalonil @ $0.15 \%)\left(20.12 \mathrm{q} / \mathrm{ha}\right.$ ) which differ non-significantly with $\mathrm{T}_{1}$ (Mancozeb@0.2\%) (20.23 q/ ha) and $\mathrm{T}_{13}$ (Chlorothalonil @ $0.3 \%)(21.32 \mathrm{q} / \mathrm{ha})$ as shown in Table 1.

The present study results revealed that $\mathrm{T}_{11}$ (Difenconazole $@ 0.05 \%$ ) and $\mathrm{T}_{10}$ (Difenconazole @0.1\%) proved best treatments with highest seed yield among other treatments for the Ludhiana. On the contrary, the minimum seed yield was observed in $\mathrm{T}_{12}$ (Chlorothalonil @0.15\%) as show in Table 1.

\section{References}

1. Allen SJ, Kochman JK, Brown JF. Effects of leaf age, host growth stage, leaf injury and pollen on the infection of sunflowers by Alternaria helianthi. Phytopathol. 1983a; 73:896-98.

2. Amaresh YS, Nargund VB, Patil BV. Integrated management of Alternaria leaf blight of sunflower, Helianthus annuus caused by Alternaria helianthi. J Oilseeds Res. 2004; 21:204-05.

3. Anonymous. Area, production and average yield of sunflower in India, 2015. http://www.indiastat.com.

4. Balasubrahmanyam N, Kolte SJ. Effect of different intensities of Alternaria blight on yield and oil content of sunflower. J Agric Sci Camb. 1980; 94:749-51.

5. Carson ML. Epidemiology and yield losses associated with Alternaria blight of sunflower. Phytopathology. 1985; 75:1151-55.

6. Dudienas C, Ungaro MRG, Moraes SA. Alternaria disease development under tropical conditions. Helia. 1998; 21:63-72.

7. Gulya JJ, Masirevic. Common names for the plant diseases of sunflower (Helianthus annuus L.) and Jerusalem artichoke (Helianthus tuberosa L.). Plant Dis. 1991; 75:30.

8. Hiremath PC, Kulkarni MS, Lokesh MS. An epiphytotic of Alternaria blight of sunflower in Karnataka. Karnataka J Agril Sci. 1990; 3:277-78.

9. Joksimovic J, Atlagic Jovanka, Marinkovic R, Jovanovi D. Genetic control of oleic and linoleic acid contents in sunflower. Helia. 2006; 29:33-40.

10. Kolte SJ. Diseases of Annual Edible Oilseed Crops. CRC Press, Florida, 1984; III:9-96.

11. Kong GA, Kochman JK, Brown JF. A greenhouse assay to screen sunflower for resistance to Alternaria helianthi. Annals Appl Biol. 1995; 127:463-78

12. Lipps PE, Herr LJ. Reaction of Helianthus annuus and Helianthus tuberosus plant introduction to Alternaria helianthi. Pl Dis. 1986; 70:831-35.

13. Mathivanan N, Prabavathy VR. Effect of carbendazim and mancozeb combination on Alternaria leaf blight and seed yield in sunflower (Helianthus annus L.). Arch Phytopathol Plant Prot. 2007; 40:90-96.
14. Mayee CD, Datar VV. Phytopathometry, Technical Bulletin-1 (Special Bulletin- 3). Marathwada Agric. Uni., Parbhani, 1986, 95.

15. Mesta RK, Sunkad G, Katti P. Chemical control of Alternaria blight of sunflower. Extended Summaries of National Seminar on Stress Management in Oilseeds for attaining self reliance in vegetable oils, January 28 - 30, held at DOR, Hyderabad, 2003, 149-51.

16. Morris JB, Yang SM, Wilson L. Reaction of Helianthus species to Alternaria helianthi. Plant Dis. 1983; 67:53940.

17. Prasad MSL, Sujatha K, Naresh N, Ramana Rao SV, Chander Rao S, Madhuri P. Seed treatment and foliar application of fungicides for the management of sunflower leaf blight. Indian J Pl Protec. 2015; 43(2):208-13.

18. Rao MA, Nageshwar Rao TG. Management of sunflower Alternaria blight [Alternaria helianthi (Hansf.)] IPS golden jubilee International Conference on Integrated Plant Diseases Management for Sustainable Agriculture held on 10-15, Nov., 1997, New Delhi, India, 1997, 359.

19. Rao MSL, Kulkarni S, Lingaraju S, Nadaf HL. Biopriming of seeds: a potential tool in the integrated management of alternaria blight of sunflower. Helia. 2009; 32(50):107-14.

20. Reddy PC, Gupta BM. Disease loss appraisal due to leaf blight of sunflowerincited by Alternaria helianthi. Indian Phytopathol. 1977; 30:569-70.

21. Shankergoud I, Shadakshari YG, Parameshwarappa KG, Chandranath HT, Katti P, Mesta RK. Sunflower and Castor Research in Karnataka - An overview, Univ. Agric. Sci. Dharwad, 2006, 1-41.

22. Sujatha M, Prabhakaran AJ, Chattopadhyay C. Reaction of wild sunflower and certain interspecific hybrids to Alternaria helianthi. Helia. 1997; 20:15-24.

23. Vijayalakshmi G, Karuna K, Mahadevaswamy G. Evaluation of Microbial Biocontrol Agents and Fungicides against Alternaria helianthi Causing Leaf Blight of Sunflower. Int J Curr Microbiol App Sci. 2018; 7(01): 2726-30.

24. Wadiphasme SS, Ingole OY, Raut NK, Asalmdle MN Chemical control of leaf spot caused by Alternaria helianthi on sunflower. Indian J Pl Prot. 1991; 19:203-05. 